\title{
WEALTH: THE ECONOMIC PREREQUISITES OF TAXATION
}

\author{
Mykhailo Sverdan'
}

\begin{abstract}
The purpose of the paper is to study the economic issues of wealth, which is the rationale and basis for the introduction of a wealth tax. This is due to current sustainable trends in wealth growth and an increase in the number of wealthy individuals. The aim is to determine the economic content, preconditions for the emergence and spread of wealth, to reflect the historical aspects of the development of wealth and its current state, to determine market conditions for the availability of wealth. At the same time, the goal is also the economic justification of wealth from the standpoint of the possibilities of its taxation. The topic of the article is due to the need to reveal the modern market infrastructure for the formation and growth of wealth, its economic status in the context of tax opportunities. In this regard, the economic essence of wealth as a potential subject of taxation is considered, the specifics of the functioning of the wealth tax in a market economy, the most important features of the functioning of the wealth tax are determined. Methodology. Economically adequate and objective justification of wealth in terms of the effectiveness of market conditions for its formation and growth allows us to assess the effectiveness of the economic system and the possibilities of public policy in the context of its taxation. This partially ensures the redistribution of public revenues, public goods and wealth. The survey is based on a theoretical generalization and analysis of empirical data on the market economy, wealth generation and its taxation. Results. The issue of wealth and its economic nature is studied. The importance of wealth for society and the state is determined. The economic specifics of wealth for its taxation are substantiated. Practical implications. Market requirements and opportunities for the formation and increase of wealth are studied. Adequate assessment of the preconditions for taxation is carried out. On this basis, the content of the wealth tax and the preconditions for its introduction are studied. The specifics of the functioning of the wealth tax in a market socially oriented economy are considered. Wealth taxation is considered from the standpoint of economic, social and fiscal efficiency. Value/originality. It was found that wealth - a comprehensive, multi-faceted category, which can be characterized as a specific feature of the socio-economic structure of society, which determines its condition, results, dynamics and development tendencies. Wealth characterizes the ability to achieve a positive result in market conditions of managing and using the existing social and economic potential in the community, as evidenced by its level of civilization development. The peculiarities of the functioning of the wealth tax in different countries of the world are considered. The using of the wealth tax as a fiscal instrument in the state tax system is suggested.
\end{abstract}

Key words: wealth, economy, taxation, property, justice, efficiency, wealth tax.

JEL Classification: E62, H22

\section{Introduction}

In the modern world, the tax is a holistic and complex social institution that has a long history and directly reflects the level of socio-economic, financial, economic and political development at a particular stage of social evolution. At the same time, the tax can also have a significant impact on the state of social, political and financial and economic systems.

In modern conditions, no country in the world can do without taxes, because they are the basis of the resource base of the state and are the main source of funding for public expenditures. And the more taxes, their structural branching - the better for the state. Another thing is how much taxes and the tax system of the state are acceptable to society, because, from a functional point of view, taxes must play not only a fiscal role, but also have a socio-economic effect. And if, according to the traditional interpretation, taxes embody the economically expressed existence of the state, then any tax for society is, above all, an additional element of the tax burden.

Taxes represent in essence a specific form of financial and economic relations between the state and society, a certain part of which is a taxpayer. These are both

\footnotetext{
Corresponding author:

${ }^{1}$ National University of Life and Environmental Sciences of Ukraine, Ukraine.

E-mail: sverdanof@ukr.net

ORCID: https://orcid.org/0000-0002-1773-3919
} 
business entities and the population in terms of its individual groups. For a certain category of citizens as taxpayers, a wealth tax is levied. Focusing on the subjects of taxation in the collection of wealth tax, it should first be noted that this is the wealthiest segment of society. The basic basis for the introduction of a wealth tax for the affluent category of society is the object of taxation - wealth. In this situation, wealth has not an arbitrary abstract form, but, instead, a clear form and a specific monetary value, which, in turn, has an individual character and personalization in relation to the taxpayer - the wealth taxpayer.

The wealth tax is also one of the youngest and oldest in world tax history. Its appearance in modern conditions occurred much later than all other types of taxes and tax payments. Wealth tax is the most perfect type of state tax in the tax system of the state, which is the most perfect form of fiscal administration in the context of individual-personal (income and property) taxation of income (property) of citizens.

\section{Economic justification of wealth taxation}

Taxes appeared as a prototype of their expression, long before the emergence of the state and the class division of society. As it developed, taxes were constantly improved: existing taxes were improved in terms of form and method of collection, the tax system was optimized, the inefficient taxes were gradually replaced by more efficient and rational ones, and new types of taxes were introduced. The latest innovation in tax practice is the introduction of a unique tax - the wealth tax. The specifics of the tax on wealth turns it into a separate, non-alternative element of the tax system of the state.

Tax systems of modern economically developed countries consist of a large list of taxes of various functional nature. The majority of taxpayers are citizens who bear the main tax burden (when paying both direct and indirect taxes). The trend of tax development is to increase the level of tax burden on citizens through the mechanisms of collecting direct taxes - on income and property (personal and real taxes). A kind of "peak" of the tax burden for citizens is the wealth tax as the latest innovation in the tax practice of the state.

During the evolution of the state and society, in unison with them, various concepts of taxation also appeared and developed, in the context of which the hypothesis of wealth taxation gradually became more and more important. In every evolutionarycivilized society there is always a wealthy segment of the population. From a fiscal point of view, it is also a taxpayer, but, unlike most taxpayers, it is generally a category with a special, more powerful tax status. First of all, there were various elements that are identified with the concept of "wealth", as well as certain luxury items, which began to act as separate, special objects of taxation. However, in contrast to the taxation of these objects, which occurs separately in the context of each of them separately, the wealth tax is quite specific in its economic nature and technique of fiscal administration. And if the issue of taxation of certain items of "wealth" and "luxury" is already quite old and quite resolved (although perhaps not definitively and with significant controversy), the issue of the introduction of "wealth tax" is relatively recent, but relevant (with even greater counter-argumentation and confrontation of interests) (Beinhocker, 2006).

The main features that distinguish the wealth tax from other taxes are: (1) taxpayers - only citizens; (2) recovery occurs in the context of personal income taxation; (3) acts as a logical continuation of property taxation; (4) collection is usually carried out (similarly to personal income tax and property taxes in most countries of the world) also on a progressive basis; (5) is imposed on the total amount of income and property (property) of citizens (James, 1978).

The wealth tax takes effect when the total amount of income and property specified in the last item (5) reaches a certain value division, which is usually quite high. It is important that the emphasis is mostly not on obtaining high incomes by citizens, but on the fact that they own a variety of property (as a result of significant financial and investment transactions and as a result of the use of significant income). Thus, a necessary precondition for the introduction of a wealth tax is the achievement of a high level of financial and property status by a "potential" taxpayer. Of course, the wealth tax becomes an additional tax burden for the payer, which is determined solely by the ability of the individual to pay the tax. Therefore, it is in the interests of the state to lay the appropriate foundations for the formation of not only a strong middle class in society, but also to create appropriate conditions for its gradual transformation into a certain elite, wealthy population, which will allow it to significantly expand tax practices and intensify tax activities, new additional taxes, including the wealth tax (Alm, 2006). This requires: (1) real provision of high incomes; (2) creation of appropriate financial market conditions and infrastructure; (3) promoting the development of the property and property market.

Thus, the necessary prerequisites for the introduction of the wealth tax and its effective functioning are: (1) the property market, as well as appropriate methods, mechanisms and tools for assessing the real market value of property; (2) the financial market, financial assets and fictitious capital (various financial instruments), as well as, similarly to the previous one, appropriate methods, mechanisms and tools for estimating their real market value.

The wealth tax is unique. The economic nature of the wealth $\operatorname{tax}$ is not so much in the possibility of obtaining significant income by citizens, as provides for the fact of their capitalization and based on the 
need to own various property (property - movable or immovable, investment - real or intangible, etc.); that is, everything has a monetary value, a monetary value and, accordingly, it is quite possible that it will be subject to tax distribution. A distinctive feature of the wealth tax is that it is imposed on the total amount of property (property) of citizens. The specifics of the tax on wealth gives it the status of an unalterable element of the tax system - as the pinnacle of tax skills of the state in maximizing the fiscal potential of taxation.

The wealth tax is the last fiscal product of the state. Wealth tax is collected independently from other taxes (personal income tax, property taxes, etc.); it functions together with them, but occupies a special, special place in the tax system of the state and in the system of taxation of income and property of citizens. An important element in the mechanism of tax collection on wealth is the subjects of taxation - the category of citizens who make up the wealthiest stratum of society. Thus, a necessary prerequisite for the introduction of wealth tax is the achievement of a "potential" taxpayer a high level of financial and property status, and the additional tax burden for the taxpayer is determined solely by the ability of citizens to pay tax. Obviously, wealthy citizens have the highest level of tax solvency.

The wealth tax is levied independently from other taxes - personal income tax, property taxes and more. It functions together with them, but occupies a special, special place in the tax system of the state and in the system of taxation of income and property of individuals. In order to achieve a high effect from the introduction of wealth tax, based on purely tax positions, you need: (1) a perfect mechanism for collecting personal income tax (in the classic, standard-traditional form); (2) perfected mechanisms for collecting property taxes, in terms of: 1) taxation of property belonging to the owner; 2) taxation of income generated by the use of property; 3 ) taxation of income from property transactions; (3) perfect mechanisms for collecting taxes on money and fictitious capital, in addition, similarly to the previous situation, also in terms of: 1) real assessment of financial and monetary assets as objects of taxation; (2) taxation of income generated by fictitious and monetary capital; 2) taxation of income from transactions with various financial instruments.

The purpose of the introduction of the wealth tax was to further strengthen the positions of the principles of social efficiency and justice in the mechanism of personal income taxation of citizens. First of all, the primary element for initiating a wealth tax is the object of taxation, which is defined as "net asset value" (total assets less liabilities). That is, for the calculation of the object of taxation is not taken individual types of property or wealth owned by citizens, and their total amount. An appropriate tax is applied to each type of property or transactions with it. The same applies to certain types of property, which are equated, according to international standards, to wealth - inheritance and gifts; however, they also have special tax regimes: inheritance tax and gift tax. These groups of taxes for the relevant objects of taxation are payable (in appropriate situations) for all citizens, regardless of their income level and financial and property status. Thus, the wealth tax is a universal fiscal category intended to be used as a practical tax instrument exclusively for wealthy citizens (Maslove, 1994).

Therefore, full or partial implementation of the wealth tax is possible. If all the above elements are not present and the introduction of a wealth tax is difficult, then effective mechanisms for collecting personal income tax and property taxes should be developed and implemented, along with the simultaneous allocation of luxury taxes (this possibility is quite obvious and real due to easier implementation).

\section{The concept of justice in the context of wealth taxation}

Analyzing the wealth tax, we must proceed from the basic premise that taxes are associated with the distribution (redistribution) of public income. The dominant hypothesis of modern tax policy is the creation of an efficient and fair tax system, which is relevant, for the most part, to the taxation of income and property of citizens; this applies to both the general tax system and each individual tax, including the wealth tax. At the same time, it is expedient to analyze not the redistributive mechanism as a whole (taking into account the process of spending taxmobilized funds), but only the fact of taxation of income (property) in terms of certain categories of taxpayers and features of collection of certain taxes (Wehner, 2011).

The principle of fairness in taxation is based on the need to evenly distribute the tax burden between taxpayers in proportion to their income. Creating a standard of "fair tax": (1) provides for equality in taxation; (2) based on the principle of solvency. The criterion of fairness (equality) characterizes the relative tax regime of different taxpayers. In economic terms, there are two main aspects of the principle of tax justice: horizontal and vertical.

Horizontal equality means direct equality of tax liabilities for all persons in the same tax position (have equal solvency, which implies equal taxation of equal income: for the same levels of income is the payment of equal amounts of taxes based on the same tax rates).

Vertical equality means that the level of taxation is set according to the degree of solvency of citizens. According to the principle of vertical fairness, people who are in an unequal position must be in an unequal tax position: if they receive more income, they must also pay more taxes (this is a tax system where different tax rates are applied depending on income level; 
this implies that the tax the burden should be progressively distributed between income levels that is, the tax rate should increase as the taxpayer's income increases, reflecting the belief that high-income taxpayers have an increased ability to pay higher taxes).

Each of the tax systems has its advantages and disadvantages. As a result, they are often used as part of a set of taxes, as virtually all countries in the world mobilize income through many different taxes. Thus, the state tries to solve the issue of tax burden, achieving the maximum possible implementation of tax principles of fairness and efficiency by creating an "optimal" model of taxation of citizens by introducing a set of taxes: (1) personal income tax; (2) property taxes (at the same time with the allocation of an additional group from them - luxury taxes); (3) wealth tax. The hierarchical construction of personal taxation is based solely on the income and property status of taxpayers, and taxes are paid only from the income of citizens (except when certain property and property are able to generate income; another situation is possible when property and property are the main source income generation). However, it is necessary to take into account and proceed from the fact that in fact the principles and mechanism of implementation of these principles of taxation in different taxes are almost the same, which ultimately gives the same effect (Bernardi, 2005).

The methodological basis for the implementation of the principle of justice is progressive taxation. According to the traditional definition, taxation is progressive if, after the payment of taxes, inequality in the economic situation of taxpayers is reduced (Bernardi, 2004).

Justice (with different concepts) is related to the taxation of personal income and is most embodied in the mechanism of personal income tax. When collecting the wealth tax, it is no longer income that is taxed, but various types of private property of citizens united in one integral complex; income serves only as a source of financing the wealth tax (similarly to the case of paying property taxes). It is also necessary to differentiate concepts and identify differences between property taxes and wealth tax. The obvious differences between property taxes and wealth tax are: (1) property taxes are paid separately for each of them separately on the same basis by all taxpayers, and the wealth tax is a complex tax that covers the total property and is paid separately from property taxes by a separate category of taxpayers; (2) the wealth tax is intended to be paid only to wealthy citizens, provided that the monetary value of their total property reaches a certain division, and the level of income, in fact, does not have a clear meaning and direct relation to this property and wealth tax.

Based on the principle of fair taxation, the wealth tax: (1) acts only as an additional element of the tax burden for wealthy citizens as taxpayers, contributing to the additional mobilization of tax revenues to the budget; (2) other categories of taxpayers do not receive anything (the level of their income does not increase, nor does the level of their wealth increase, and the amount of tax liabilities does not decrease). That is, both the level of income and financial and property status, and the tax position and level of tax solvency of other categories of citizens - taxpayers who are not taxpayers of wealth, remain completely unchanged; in principle, this situation cannot change, as the purpose of introducing a wealth tax is to achieve completely different goals (Slemrod, 1999).

The separation of "vertical" and "horizontal" justice does not allow to solve one of the main tasks that exist in the tax sphere: how to determine the degree of fairness of taxation? After all, for wealthy citizens - wealth tax payers - only increases the level of tax burden. If we assume that the tax policy of the state should be based on the principles of redistribution of tax payments between taxpayers with different opportunities, it means that the very idea of "uniformity in taxation" is unconvincing and even unprofitable. The principle of justice is understood differently. The problem here is that justice is a category, first of all, social, moral and ethical; in economics, however, it is an "alien" element, a relatively relative concept, subjective in nature and therefore far from ambiguous. Different notions of justice give rise to different notions of economic and tax justice. The choice of directions for reforming the tax system and different taxation mechanisms should be made taking into account the presence among potential taxpayers of different groups, which are united by the ability to bear the same tax burden. On this basis, a separate category of taxpayers (wealthy citizens) is allocated and a special type of state tax is introduced: the wealth tax (Sverdan, 2020).

Thus, balancing is a relatively relative concept: at best, it is only partially realized only in the mechanism of personal income tax payment and is hardly inherent in the collection of property taxes (including luxury taxes); therefore, with regard to the collection of the wealth tax, it can be stated that even the relative effect of balancing is absent at all. It also argues that fairness in taxation does not involve balancing income and wealth between different categories of taxpayers; no tax, including the wealth tax, can ensure this. In this case, it is appropriate to emphasize that fairness in the redistribution of income is realized only at the level of the relevant category of wealth taxpayers, and their financial and property status allows to allocate additional taxation and with the help of wealth tax to increase tax revenues.

\section{Fiscal expediency of wealth taxation}

The practice of implementing the wealth tax shows the presence in the country that practices it, a significant number of citizens who pay it. At the same 
time, this is evidenced by the fact that the country's population has the opportunity to receive high incomes, which are taxed not only on a progressive scale in the personal income tax mechanism, but also allow the state to introduce additional higher tax regimes. This is reflected, in particular, through wealth taxes.

The introduction of wealth taxes into fiscal practice is evidenced by the fact that taxation is at a fairly high level of social (socio-economic) evolution, a fairly high degree of civilized perception of tax matters and, to the same extent - fiscal democracy.

Wealth taxes in the modern world are quite rare. Moreover, the trends of tax practice over the past decades allow us to state unequivocally the gradual and quite obvious reduction of the mechanisms of wealth taxation. In today's world, there are hardly a dozen countries in the global international environment where the fiscal practice of wealth taxation takes place. Most countries once abandoned the practice of wealth tax. However, the consequences of the financial and economic crisis of 2008 prompted European countries to recover the wealth tax, as its fiscal efficiency is quite significant and can be quite a significant part of tax revenues (Grahl, 2009).

The possibility of introducing the functioning of the wealth tax is influenced by a number of factors of various kinds: most of all it concerns the financial and economic basis of its existence, and recently it is also significantly influenced by the political factor (McCready, 1992).

Taxes is the main type of state budget revenues. The issue of fiscal adequacy of taxation always remains important and relevant, as the obvious trend in the development of modern tax systems is the lack of mobilization of tax revenues.

The main task in this situation is to find alternative sources of tax revenue that has national financial significance. This can ensure the strengthening of the financial and economic system in the country and the stabilization of the budget system of the state as a whole. Therefore, it is necessary to find additional tax reserves as one of the ways to modernize the tax system and improve the financial situation in the country.

Market-developed countries around the world are constantly transforming and adjusting tax systems. The main dominant features of tax policy - dynamics, mobility, efficiency. According to these criteria, the construction and development of modern tax systems. According to them, tax reforms are being implemented, which focus on improving tax systems and mechanisms for collecting certain taxes. Also, there may be processes of improvement and expansion of certain groups of taxes.

In economically developed countries, income and consumption taxation systems have been formed and function effectively for a long time. In addition, a significant source of accumulation of tax revenues are also property taxes, which constitute a potential and quite powerful tax reserve. Typically, the category of property taxes includes land tax and an extensive system of property taxes, which also include inheritance and gift taxes. In addition, in countries with market economies, another element of them functions effectively - the wealth tax as a unique integrated form of private property taxation. The experience of using the wealth tax is quite long - not only in economically developed countries, but also in many other countries. Its popularity was especially evident in Western Europe (Andersson, 2007) and Latin America (Lymer, 2002).

The economic nature of the wealth tax is not only the ability of an individual to receive significant income, but also includes the fact of ownership of various property (property - movable or immovable, investment - real or intangible, etc.). In any case, everything has a monetary value, a monetary value and, accordingly, it is quite possible that it will be subject to tax distribution. The fiscal nature of the wealth tax is a comprehensive taxation of wealth (income and property) exclusively of wealthy citizens. The content of the wealth tax is revealed by the fact that the payer of personal income tax reaches a fairly high level of its financial and property status, which gives the state the potential to introduce it and mobilize additional funds to the budget. In fact, the wealth tax itself is, in fact, an additional tax on wealthy citizens in the context of personal income taxation.

Thus, for the effective use of the wealth tax is necessary for the effective functioning of the current tax system of the state, especially - personal income tax. Obviously, in this context, an important prerequisite for the likelihood of the introduction of a wealth tax is the presence of property taxes (property). But first of all, it is a perfect mechanism of personal income taxation, and further - a mechanism of property taxation, which operates in the context of personal income taxation. The perfection of the mechanism of personal income taxation and experience in collecting property taxes are the basis for the introduction of wealth tax (Messere, 1998).

It is obvious that the wealth tax is an additional burden for wealthy citizens in the context of personal income and property taxation. And the smaller the individual deduction (non-taxable minimum, or taxfree threshold), the more opportunities to initiate a wealth tax. From a fiscal point of view, this is more profitable because it automatically increases the number of wealth taxpayers, which, objectively, are much smaller than other taxes. In any case, the fiscal efficiency of the wealth tax is successfully realized through an organic combination of elements of its collection: a high object of taxation and low tax rates. The limited number of wealth taxpayers and low tax rates are well offset by the significant size of taxable 
items. Thus, due to this, the fiscal efficiency of the wealth tax can be quite significant. The relatively low level of the tax-free minimum automatically determines a fairly large number of wealth taxpayers.

Thus, from a fiscal point of view, the wealth tax is full, well-founded, efficient and fair. At the level of the whole set of taxpayers, the fiscal fairness of the wealth tax is embodied in the fact that its collection provides significant individual discounts and deductions, which significantly reduces the tax burden: the exemptions significantly increase the tax-free minimum, as some private property is not included to the taxable base.

In addition, there is a special fiscal limit in the context of the collection of wealth tax, which sets a certain quota of taxes paid. According to this standard, the total amount of tax liabilities should not exceed a certain division: the total tax mass, which includes personal income tax and wealth tax, should not exceed the corresponding percentage. Thus, so that the tax burden for a particular category of citizens is not too discriminatory, there is a set of tools to establish the position of fiscal justice.

The social significance of the wealth tax is also important for society. Taxation is generally viewed in terms of social justice. The wealth tax greatly contributes to further strengthening the position of social justice of taxation, as its potential allows us to implement the principle: the rich pay more (Hallerberg, 2009).

Thus, the wealth $\operatorname{tax}$ is market-adequate, socially acceptable and fiscally efficient, which is guaranteed to give it a proper place in the tax system of the state.

The experience of using the wealth tax in foreign countries clearly demonstrates the fact that the annual number of its payers is growing. The presence of a taxpayer is the basis for the introduction of any tax. And for each type of tax there is a corresponding object of taxation. With regard to the wealth tax, the object of taxation is quite specific. In addition, the number of taxpayers in the context of wealth taxation is the lowest compared to other types of taxes. However, the fiscal efficiency of the wealth tax is significantly enhanced by the object of taxation and the tax base and turns it into a universal fiscal instrument of the state in the system of taxation of income, property (property) of a certain category of the population in society.

\section{Conclusions}

Given this characteristic, it should be noted that the fact of the introduction of the wealth tax is not a natural accident, but a complex and lengthy process consisting of numerous procedures. First of all, it is the experience of tax practice and the perfection of the collection of existing taxes: the high level of tax efficiency is currently the basis for modifying existing taxes and modernizing the tax system by introducing new types of taxes, including wealth tax. Another essential prerequisite for the introduction of a wealth tax is the development of the market, market relations and market institutions, in particular - the institution of property and financial institutions, ensuring their branching and effective functionality. Without this, the introduction of a wealth tax will be either significantly complicated or ineffective in the nature of its practice. The determining element for initiating and activating the wealth tax is the income of the population - the basis of wealth, its creation and increase.

Full or partial implementation of the wealth tax is possible. If all the necessary elements are not available and the introduction of a wealth tax is difficult, then effective mechanisms for collecting personal income tax and property taxes should be developed and implemented, while allocating luxury taxes among them (this possibility is quite obvious and real due to easier implementation). The wealth tax is levied autonomously from other taxes; it functions together with them, but occupies a special place in the tax system of the state and in the system of taxation of income and property of citizens.

\section{References:}

Alm, J., Martinez-Vazqez, J., \& Rider, M. (2006). The challenges of tax reform in a global economy. New York: Springer. $\mathrm{x}, 474 \mathrm{p}$.

Andersson, K., Eberhartinger, E., \& Oxelheim, L. (2007). National Tax Policy in Europe: To Be or Not to Be? Berlin: Heidelberg Springer, xiii, 255 p.

Beinhocker, E. D. (2006). The origin of wealth: evolution, complexity, and the radical remaking of economics. Boston: Harvard Business School Press, xvi, 527 p.

Bernardi, L., Chandler, M. S. W., Gandullia, L., \& Tanzi, V. (2005). Tax systems and tax reforms in new EU members. $\mathrm{xxv}, 258 \mathrm{p}$.

Bernardi, L., Profeta, P., \& Tanzi, V. (2004). Tax systems and tax reforms in Europe. London; New York: Routledge, xxviii, 305 p.

Grahl, J. (2009). Global finance and social Europe. Cheltenham: Northampton: Edward Elgar, xxi, 317 p.

Hallerberg, M., Strauch, R. R., \& Hagen, J. von (2009). Fiscal governance in Europe. Cambridge; New York: Cambridge University Press, $\mathrm{x}, 230 \mathrm{p}$.

James, S., \& Nobes, C. (1978). The economics of taxation. Oxford: P. Allan, x, 310 p. 
Vol. 2 No. 1, 2021

Lymer, A., \& Hasseldine, J. (2002). The international taxation system. Boston: Kluwer Academic Publishers, xiii, $319 \mathrm{p}$

Maslove, A. M. (1994). Issues in the taxation of individuals. Toronto; Buffalo: University of Toronto Press in cooperation with Fair Tax Commission of Ontario, 1994, xiv, 260 p.

McCready, D. J. (1992). Wealth taxes: further arguments against. Canadian Public Administration, 35(4), pp. 534-538.

Messere, K. (1998). The tax system in industrialized countries. Oxford; New York: Oxford University Press, xix, 430 p.

Slemrod, J. (1999). Tax policy in the real world. Cambridge; New York: Cambridge University Press, x, 515 p.

Sverdan, M. (2020). Economics and taxation of wealth. Three Seas Economic Journal, 4(1), pp. 126-132.

Wehner, P., Brooks, A. C., \& Jenkins, P. (2011). Wealth \& justice: the morality of democratic capitalism. Washington, D.C.: AEI Press; Summit Distributed by the National Book Network, xxi, 67 p. 